\title{
Influence of Hydration Treatments on Seedling Characters of Soybean (Glycine max L.)
}

\author{
J. Hemasruthi ${ }^{1 *}$, Kandula Uma Maheswari ${ }^{1}$, Prashant Kumar Rai ${ }^{1}$, \\ Pulivarthi Vineela ${ }^{1}$ and N. Bhavana Stella ${ }^{2}$
}

${ }^{1}$ Department of Genetics and Plant Breeding, Naini Agricultural Institute, Sam Higginbottom

University of Agriculture, Technology and Sciences, Prayagraj, U. P., India

${ }^{2}$ Director, State Institute for Management of Agriculture, Department of Agriculture, Govt. of

Uttar Pradesh, India

*Corresponding author

\section{A B S T R A C T}

\begin{tabular}{l} 
Key w o r d s \\
Soybean, $\mathrm{PEG}$ \\
$\begin{array}{l}\text { 6000, } \mathrm{KNO}_{3}, \\
\text { Moringa leaf } \\
\text { extract, Hydration } \\
\text { and germination }\end{array}$ \\
\hline Article Info \\
\hline $\begin{array}{l}\text { Accepted: } \\
18 \text { November } 2020 \\
\text { Available Online: } \\
\text { 10 December } 2020\end{array}$ \\
\hline
\end{tabular}

Soybean (Glycine $\max (\mathrm{L}$.$) Merr.), a good source of protein and oil, is used to produce$ nutritious is of lavone-rich soybean-based foods. The present investigation "Influence Of Hydration Treatments On Seedling Characters Of Soybean (Glycine max L.)" is carried out in the Post graduate laboratory, Department of Genetics and Plant Breeding and P.G. Laboratory, Department of biochemistry (JIBB),Sam Higginbottom University of Agriculture, Technology \& Sciences, Prayagraj, Uttar Pradesh, India during 2019-2020, to assess the potential of botanicals for germination, seedling vigour and germination index in Soybean. Inorganic and organic priming methods were adopted and treatments used are as $\mathrm{T}_{0}(\mathrm{Control}), \mathrm{T}_{1}$-Zinc sulphate $\left(\mathrm{ZnSO}_{4}\right)(2 \%), \mathrm{T}_{2}$ - Magnesium sulphate $\left(\mathrm{MgSO}_{4}\right)(2 \%)$, $\mathrm{T}_{3}$-Potassium chloride $(\mathrm{KCl})(2 \%), \mathrm{T}_{4}$ - Potassium nitrate $\left(\mathrm{KNO}_{3}\right)(2 \%), \mathrm{T}_{5}$-Polyethylene Glycol (PEG) 6000nm(20\%), $\mathrm{T}_{6}$-Salicylic acid (2\%), $\mathrm{T}_{7}-$ Moringa leaf extract $(5 \%), \mathrm{T}_{8}-$ Curry leaf extract $(5 \%), \mathrm{T}_{9^{-}}$- Mint leaf extract $(5 \%) \quad \mathrm{T}_{10}$ - Neem leaf extract $(5 \%)$. The experiment was laid out in completely randomized design (CRD) having four replications. Among all the treatments PEG $6000 \mathrm{~nm}$ recorded high germination percentage, germination energy, root length, shoot length, seedling length, fresh and dry weight of seedling, seed vigor index length and seed vigor index mass. However, there is no much significant difference in the protien content of seeds hydrated with botanicals and chemicals compared to control. The results indicate that the use of PEG6000 enhances the seed performance regarding germination and vigor. The process is simple and in economy as no costly equipment is required to overcome the poor germination and poor seedling establishment.

\section{Introduction}

Grain legumes are second in importance to human and animal diets after cereals and occupy an important place in the world's food and nutrition economy. Being the primary source of high quality dietary protein, grain legumes are important in alleviating protein deficiency and malnutrition prevailing among poor people in developing countries, as well 
as contributing significantly to global food and nutritional security. In addition to food and fodder, the nitrogen fixing capacity of grain legumes decreases the need for direct application of $\mathrm{N}$-fertilizers and makes them an important component in cropping systems for improving and sustaining soil fertility and texture (Graham and Vance, 2003).

Soybean, (Glycine max), also called sojabean, with the chromosome number $2 n=40$. Soybean is an annual legume of the pea family (Fabaceae) and its edible seed. The soybean is economically the most important bean in the world, providing vegetable protein for millions of people and ingredients for hundreds of chemical products. Soybeans contain significant amounts of phytic acid, dietary minerals and $B$ vitamins. Soy vegetable oil, used in food and industrial applications, is another product of processing the soybean crop. Soybean is the most important protein source for feed farm animals (that in turn yields animal protein for human consumption). Soybean oil is the world's most widely used edible oil, as it is low in cholesterol, with a natural taste and nearly imperceptible odour, which makes it the ultimate choice of vegetable oil for domestic and industrial food processing (Mpepereki et al., 2000; AddoQuaye et al., 1993).

The word soy is derived from the Chinese or Japanese word meaning soya sauce. Based on the sweetness, the Greek word for sweet, glykos, was Latinized. The genus name is not related to the amino acid glycine. The protein of soybean is glycinin and conglycinin. The soybean seed contains rich amount of oil and protein. Because soybeans contain no starch they are a good source of protein for diabetics. Soy bean is also known as golden beans an due to its high protein content it is also known as "miracle crop". Soybean is also known as vegetable meat.
As Soybean is legume crop it plays a significant role in improving the soil fertility by fixing the atmospheric nitrogen. Soybean meets its $50 \%$ of the nitrogen requirement from symbiotic nitrogen fixation. It leaves plenty of organic matter to maintain and improve soil health and fertility due to its long tap root system and it can also withstand drought conditions by extracting water from deeper layers in the soil profile.

Soybeans are rich in proteins ranging $36-40 \%$, lipid levels between 18-20\%and oil of $22 \%$.Soybeans are low in saturated fat and high in protein, vitamin $\mathrm{C}$, and folate. They are also a good source of Calcium of $197 \mathrm{mg}$, Iron of $3.55 \mathrm{mg}$, magnesium of $65 \mathrm{mg}$, Phosphorus 194mg, potassium $620 \mathrm{mg}$, and thiamin. The poor growth of the seed may occur due to poor nutrient quality of the seed, lack of moisture, low viability of the seed etc. the seed germination can be increased by seed quality enhancement techniques such as seed priming, hydration and dehydration treatments, seed invigoration etc. there by we can increase the nutritional quality of the seed.

Seed priming is a physiological method of controlled hydration and drying to enhance sufficient pre-germinative metabolic process for rapid germination (Dawood 2018). Basically it's a pre sowing treatment in which seeds were soaked in some way at a moisture level sufficient to initiate the early stages of germination (imbibitions) but not sufficient to emit radical protrusion. It's a technique for controlling seed slow absorption and post dehydration. Seed priming has presented promising, and even surprising results, for many results including the legume seeds (Bradford, 1986) the few studies on soybean are not over emphasized and are encouraging, but more information is required before its use as a routine practice in seed technology. 
According to khan (1992), osmotic conditioning in its modern sense, aims to reduce the time of seedling emergence, as well as synchronize and improves the germination percentage by subjecting the seeds of certain period of imbibitions using osmotic solutions.

The seeds normally begin water uptake on contact with this solution stop the process as soon as they become balanced with the water potential of the solution. Rapid germination and emergence is an important factor for successful establishment.

\section{Materials and Methods}

The present investigation "Influence Of Hydration Treatments On Seedling Characters Of Soybean (Glycine max L.)" is carried out in the Post graduate laboratory, Department of Genetics and Plant Breeding and P.G. Laboratory, Department of biochemistry (JIBB), Sam Higginbottom University of Agriculture, Technology \& Sciences, Prayagraj, Uttar Pradesh, India during 20192020 , to assess the potential of botanicals for germination, seedling vigour and germination index in Soybean.

The data was collected on ten randomly selected healthy seedlings plants from each replication and different observations were recorded. Inorganic and organic priming methods were adopted and treatments used are as $\mathrm{T}_{0}$ (Control), $\mathrm{T}_{1}$-Zinc sulphate $\left(\mathrm{ZnSO}_{4}\right) \quad(2 \%), \quad \mathrm{T}_{2}$-Magnesium sulphate $\left(\mathrm{MgSO}_{4}\right)(2 \%), \mathrm{T}_{3}$-Potassium chloride $(\mathrm{KCl})$ $(2 \%), \mathrm{T}_{4}$ - Potassium nitrate $\left(\mathrm{KNO}_{3}\right)(2 \%), \mathrm{T}_{5}$ Polyethylene Glycol (PEG) 6000nm (20\%), $\mathrm{T}_{6}$-Salicylic acid (2\%), $\mathrm{T}_{7}$ - Moringa leaf extract $(5 \%), \mathrm{T}_{8}-$ Curry leaf extract $(5 \%), \mathrm{T}_{9}$ Mint leaf extract $(5 \%) \mathrm{T}_{10}$ - Neem leaf extract $(5 \%)$. The estimation of protein was done by Lowry's method (1951).

\section{Preparation of solutions}

The solution of (2\%)was prepared by dissolving 2 gms of chemical in $100 \mathrm{ml}$ of distilled water each in separate beakers for making chemical solutions respectively. For the preparation of botanical leaf extracts Moringa, Curry leaf, neem, Mint leaves were collected from Horticulture Research fields, SHUATS. These leaves were shade dried and made into fine powder.5g of each powder is dissolved in $100 \mathrm{ml}$ of distilled water to make $5 \%$ solution

After preparation of solutions, seeds were soaked in for a duration of 6hrs and shade dried. These seeds were used for further laboratory studies to record observations.

\section{Results and Discussion}

It is evident from the present investigation that hydration treatments with chemicals and botanicals have significant effect on quality parameters in Soybean. In general, most of the treatments have increased germination and vigour parameters as compared to control (untreated seeds).

The study reveals that seeds primed with PEG 6000 nm@20\% hydrated for 6 hrs $\left(\mathrm{T}_{5}\right)$ recorded maximum value for germination percentage $(89 \%)$, germination energy $(48 \%)$, shoot length $(16.25 \mathrm{~cm})$, root length $(13.15 \mathrm{~cm})$, seedling length $(29.41 \mathrm{~cm})$, seedling fresh weight ( $7.17 \mathrm{gms})$, seedling dry weight $(1.22 \mathrm{gm})$, seedling vigour index I (2617) and vigour index II (109.45). And the second highest was recorded for $\mathrm{KNO}_{3}$ with germination percentage $(88 \%)$, germination energy (46.5), shoot length (15.9), root length $(12.89 \mathrm{~cm})$, seedling length $(29.41 \mathrm{~cm})$, seedling fresh weight $(7.08 \mathrm{gms})$ seedling dry weight (1.18gms), seedling vigour index I (2534) and seedling vigour index II (105.15) (Table 1 and 2). 
Table.1 Mean performance of seed quality parameters due to various priming treatments in Soybean

\begin{tabular}{|c|c|c|c|c|c|c|c|c|c|}
\hline $\begin{array}{l}\text { Treatme } \\
\text { nt } \\
\text { symbol }\end{array}$ & $\begin{array}{c}\text { Germination } \\
(\%)\end{array}$ & $\begin{array}{c}\text { Germinat } \\
\text { ion } \\
\text { energy }\end{array}$ & $\begin{array}{l}\text { Root } \\
\text { length }\end{array}$ & $\begin{array}{l}\text { Shoot } \\
\text { length }\end{array}$ & $\begin{array}{l}\text { Seedling } \\
\text { length }\end{array}$ & $\begin{array}{c}\text { Seedling } \\
\text { fresh } \\
\text { weight }\end{array}$ & $\begin{array}{c}\text { Seedling } \\
\text { dry } \\
\text { weight }\end{array}$ & $\begin{array}{c}\text { Seed } \\
\text { vigour } \\
\text { index-1 }\end{array}$ & $\begin{array}{l}\text { Seed vigour } \\
\text { index-2 }\end{array}$ \\
\hline $\mathbf{T}_{\mathbf{0}}$ & 69.00 & 37.5 & 12.85 & 10.83 & 23.67 & 6.63 & 1.04 & 1633 & 71.95 \\
\hline $\mathbf{T}_{1}$ & 85.50 & 42 & 15.44 & 11.51 & 26.94 & 6.78 & 1.08 & 2304 & 94.03 \\
\hline $\mathbf{T}_{2}$ & 83.75 & 43.25 & 15.20 & 12.33 & 27.53 & 6.91 & 1.07 & 2305 & 88.16 \\
\hline $\mathbf{T}_{3}$ & 85.5 & 43 & 14.97 & 12.40 & 27.37 & 6.87 & 1.11 & 2340 & 96.4 \\
\hline $\mathbf{T}_{4}$ & 88 & 46.5 & 15.9 & 12.89 & 28.79 & 7.08 & 1.18 & 2534 & 105.15 \\
\hline $\mathbf{T}_{5}$ & 89 & 48 & 16.25 & 13.15 & 29.41 & 7.17 & 1.22 & 2617 & 109.45 \\
\hline$T_{6}$ & 84.25 & 44 & 15.02 & 12.45 & 27.47 & 6.72 & 1.10 & 2315 & 93.73 \\
\hline $\mathbf{T}_{7}$ & 87 & 45 & 15.55 & 12.83 & 28.39 & 6.96 & 1.18 & 2470 & 103.1 \\
\hline $\mathbf{T}_{8}$ & 83.75 & 41 & 14.72 & 12.39 & 27.11 & 6.68 & 1.10 & 2270 & 92.55 \\
\hline $\mathbf{T}_{9}$ & 83.5 & 42 & 15.25 & 12.51 & 27.76 & 6.78 & 1.07 & 2318 & 89.34 \\
\hline $\mathbf{T}_{10}$ & 86 & 41.75 & 15.43 & 12.73 & 28.16 & 6.94 & 1.17 & 2423 & 100.16 \\
\hline Mean & 84.11 & 43.09 & 15.14 & 12.36 & 27.50 & 6.86 & 1.12 & 2320.18 & 94.91 \\
\hline F. & $\mathrm{S}$ & S & $\mathrm{S}$ & $\mathrm{S}$ & S & S & S & S & S \\
\hline C.D. & 2.837 & 3.351 & 0.615 & 0.411 & 0.755 & 0.065 & 0.040 & 104.04 & 4.145 \\
\hline S.E.(m) & 0.982 & 1.160 & 0.213 & 0.142 & 0.261 & 0.023 & 0.014 & 36 & 1.434 \\
\hline S.E.(d) & 1.389 & 1.640 & 0.301 & 0.201 & 0.369 & 0032 & 0.02 & 50.91 & 2.028 \\
\hline C.V. & 2.335 & 5.382 & 2.809 & 2.299 & 1.898 & 0.659 & 2.476 & 3.102 & 3.022 \\
\hline
\end{tabular}

Table.2 Influence of hydration treatments on protein in soybean seeds

\begin{tabular}{|l|c|c|}
\hline Treatment & O.D at 660 nm & Protein Percentage \\
\hline $\mathbf{T}_{\mathbf{0}}$ & 0.55 & $35.39 \%$ \\
\hline $\mathbf{T}_{\mathbf{4}}$ & 0.57 & $36.68 \%$ \\
\hline $\mathbf{T}_{\mathbf{5}}$ & 0.564 & $36.29 \%$ \\
\hline $\mathbf{T}_{\mathbf{7}}$ & 0.561 & $36.1 \%$ \\
\hline $\mathbf{T}_{\mathbf{1 0}}$ & 0.557 & 35.84 \\
\hline
\end{tabular}


Similar results was obtained by H. Sadeghi et al., (2011), Duman (2006), Leila Yari et al., (2010), Tian et al., (2014), Abdullahil Baque et al., (2016), Shivashu Singh et al.,(2015).

The results also indicate that hydration method had little influence on protein content of soybean seeds. The O.D values obtained are taken from the spectrophotometer at $660 \mathrm{~nm}$ and then the protein percentage is calculated.

In conclusion based on the present investigation, hydration of soybean seeds with chemicals and botanicals shown a high performance in germination and vigour parameters of the seeds than control comparatively. Seed treatment with Poly ethylene glycol (PEG6000) @20\%for 6 hours shown significant values of germination percentage, germination energy, seedling length, fresh and dry weight of seedling and seed vigour index I and seed vigor index II. among all the treatments in soybean followed by Potassium Nitrate $\left(\mathrm{KNO}_{3}\right)$ and Moringa leaf extract. The results also indicates that hydration method had little influence on protein content of soybean seeds.

\section{References}

Abdul-Baki, A. A., and Anderson, J. D. (1973). Vigor determination in soybean seed by multiple criteria 1 . Crop science, 13(6), 630-633.

Abdulrahmani, B., Ghassemi-Golezani, K., Valizadeh, M., and Asl, V. F. (2007). Seed priming and seedling establishment of barley (Hordeum vulgare L.). Journal of Food Agriculture and Environment, 5(3/4), 179.

Bradford, K. J., Steiner, J. J., and Trawatha, S. E. (1990). Seed priming influence on germination and emergence of pepper seed lots. Crop Science, 30(3),
718-721.

Copeland, L.O. and Mcdonald, M.B. 1995, Principles of Seed Science and Technology,(3th Ed) . Chapman and Hill, New York.

Chawla, N., and Pathak, M. (2015). Effect of different seed priming treatments and priming duration on biochemical parameters and agronomic characters of okra (Abelmoschus esculentus L.). International Journal of Plant Physiology and Biochemistry, 7(1), 111.

Dawood, M. G. (2018). Stimulating plant tolerance against abiotic stress through seed priming. In Advances in Seed Priming (pp. 147-183). Springer, Singapore.

Duman, I., 2006. Effects of seed priming with PEG and $\mathrm{K}_{3} \mathrm{PO}_{4}$ on germination and seedling growth in Letluce. Pak. J. Biol. Sci., 9(5): 923-928.

El-Adawy, T. A., Rahma, E. H., El-Bedawy, A. A., \& Sobihah, T. Y. (2000). Effect of soaking process on nutritional quality and protein solubility of some legume seeds. Food/Nahrung, 44(5), 339-343.

Farooq, M. S. M. A., Basra, S. M. A., Saleem, B. A., Nafees, M., \& Chishti, S. A. (2005). Enhancement of tomato seed germination and seedling vigor by osmopriming. Pak. J. Agri. Sci, 42, 34.

Farahbakhsh (2012) reported that the concentration of 0.25 and $0.5 \mathrm{mM}$ of salicylic acid on germination, germination rate, seed stamina index, hypocotyl length, radical length and seedling fresh (Foeniculum vulgare) was more effective as compared to other levels ( 0 and $0.75 \mathrm{mM}$ ).

Ghassemi G, Aliloo AA, Valizadeh M, Moghaddam M. (2008). Effect of Hydro and osmopriming on seed germination and field emergence of 
Lentil. Notulae Botanicae Horti Agrobotanici Cluj- Napoca.

Graham, P. H., and Vance, C. P. (2003). Legumes: importance and constraints to greater use. Plant Physiology, 131(3), 872-877.

International Seed Testing Association, ISTA (2011). International Rules for Seed Testing. Zurichstr. CH-8303 Bassersdorf, Switzerland

Khan, A. A. (1992). Preplant physiological seed conditioning. Horticultural reviews, 13(1), 131-181.

Khajeh-Hosseini M., Powell A.A. and Bingham IJ. (2003). The interaction between salinity stress and seed vigour during germination of soybean seeds. Seed Science and Technology. 31: 715-725Kaur, H.,

L.Yari, Aghaalikani, M., and Khazaei, F. (2010). Effect of seed priming duration and temperature on seed germination behavior of bread wheat (Triticum aestivum L.). ARPN Journal of Agricultural and Biological Science, 5(1), 1-6.

Lowry, O. H., Rosebrough, N. J., Farr, A. L., \& Randall, R. J. (1951). Protein measurement with the Folin phenol reagent. Journal of biological chemistry, 193, 265-275.

Matthews, S., 1980. Controlled deterioration: a new vigour test for crop seeds. In: Hebblethwaite PD, ed. Seed production. London: Butterworths, 513-526.

Mpepereki, S., Javaheri, F., Davis, P. (2000).
Soybean and Sustainable Agriculture: Promiscuous Soybean in Southern Africa. Field Crops Res 63, 137 - 149.

Pegah MD, Sharif-zadeh F and Janmohammadi M. (2008). Influence of priming techniques on seed germination behavior of maize inbred lines (Zea mays L.). ARPN Journal of Agricultural and Biological Science 3: 22-25.

Ruan S., Q. Xue and K. Tylkowska. 2002. The influence of priming on germination of rice Oryza sativa $\mathrm{L}$. seeds and seedling emergence and performance in flooded soil. Seed Sci. Technol. 30: 61-67.

Sadeghi, H., Khazaei, F., Yari, L., and Sheidaei, S. (2011). Effect of seed osmopriming on seed germination behavior and vigor of soybean (Glycine max L.). ARPN Journal of Agricultural and Biological Science, 6(1), 39-43.

Singh, S., Lal, G. M., Bara, B. M., and Mishra, S. N. (2017). Effect of hydropriming and osmopriming on seed vigour and germination of Pea (Pisum sativum L.) seeds. $J$. Pharmacognosy and Phytochemistry, 6(3), 820-824.

Y.Tian, Guan, B., Zhou, D., Yu, J., Li, G., \& Lou, Y. (2014). Responses of seed germination, seedling growth, and seed yield traits to seed pretreatment in maize (Zea mays L.). The Scientific World Journal, 2014.

\section{How to cite this article:}

Hemasruthi, J., Kandula Uma Maheswari, Prashant Kumar Rai, Pulivarthi Vineela and Bhavana Stella, N. 2020. Influence of Hydration Treatments on Seedling Characters of Soybean (Glycine max L.). Int.J.Curr.Microbiol.App.Sci. 9(12): 2697-2702. doi: https://doi.org/10.20546/ijcmas.2020.912.319 